\title{
THE RELATIONSHIP BETWEEN THE NUMBER OF TOURISTS ARRIVED IN ROMANIA'S DEVELOPMENT REGIONS AND THE GROSS DOMESTIC PRODUCT
}

\author{
Mirea Cosmin Nicolae ${ }^{\mathbf{1}}$, Sârbu Alexandra Maria ${ }^{2 *}$, Ionescu Andra Maria ${ }^{3}$ \\ ${ }^{1}$ Bucharest University of Economic Studies, Romania, cosminnicolaemirea@ gmail.com \\ ${ }^{2}$ Bucharest University of Economic Studies, Romania, alexandramariasarbu@gmail.com \\ ${ }^{3}$ Central Europe - Unilever, Romania, Andra.Ionescu@unilever.com
}

\begin{abstract}
At national level, the contribution of tourism to the formation of the Gross Domestic Product is quite significant, considering the year 2019, when the contribution of tourism was 6.1\% (World Travel \& Tourism Council, 2021). Thus, the connection between tourism and Gross Domestic Product is indisputable. The purpose of this study is to find out the influence of the number of tourists arriving in the development regions of Romania on the Gross Domestic Product. The regression method was applied for data processing, using the statistical program EViews. The highest increase in the Gross Domestic Product, depending on the increase in the number of tourists, is registered in the South-Muntenia Development Region, and the smallest increase is registered in the BucharestIlfov Development Region. The results show that a large number of tourists does not necessarily mean generating a considerable increase in Gross Domestic Product.
\end{abstract}

Keywords:

Tourists, Gross Domestic Product, Development Regions, Regression

JEL Classification: Z30, Z32

DOI: $10.24818 / \mathrm{CTS} / 3 / 2021 / 1.02$

\section{Introduction}

Globally, tourism is one of the most important economic sectors in terms of contributing to the formation of the global Gross Domestic Product. At national or regional level, the contribution of tourism to the formation of the Gross Domestic Product may differ depending on a series of factors, such as the number of tourists, length of stay, expenses incurred by tourists etc. Also, the contribution of tourism in the entire economy can be found by relating the entire tourism sector to GDP (Gross Domestic Product), but also by reporting the number of employees in tourism to the total number of employees in the entire economy (Popescu, et al., 2018, p. 606). In this study, the number of tourists will be related to GDP, in order to find out the influence of the number of tourists on GDP. Regarding the tourism intensity, represented by the number of tourists arriving in different regions, it can be admitted that it can generate advantages, such as increasing living standards, but can also generate disadvantages, such as increasing pressure on the regions visited.

In general, the number of tourists generates economic growth, with a positive link between these two elements, as is the case with 81 regions in Turkey (Karagozzeren, 2018). The positive link can be explained by the fact that tourists spend in the tourist destinations they visit, which means a monetary surplus in the local, regional or even national economy. Thus, tourists as part of the tourism phenomenon, can contribute to the formation of the Gross Domestic Product of a country. Regarding the development regions of Romania, differences were identified regarding the contribution in the formation of the Gross Domestic Product. Thus, Pripoaie (2017, p. 214) concludes that the development regions of Romania depend on different economic sectors, for example the South-East, South-Muntenia and South-West Oltenia Development Regions depend on the agricultural sector, and the North-East and South-East Development Regions depend on the tourism sector. In other words, the agricultural and tourist potential of the development regions represents an important factor in the formation of the Gross

\footnotetext{
* Contact author
} 
Domestic Product of Romania. Thus, the tourist potential must be capitalized at its true value to attract tourists and, implicitly, money in the regional and national economy, especially since at the level of the whole country, the elasticity of the Gross Domestic Product according to the tourist demand is positive and significant in the long run (Lazăr and Pop, 2012, p. 10).

This paper is structured as follows: the literature on tourism in the development regions of Romania and the relationship between tourism and Gross Domestic Product, research methodology, results and conclusions.

\section{Literature review}

\subsection{Regional tourism}

The region is an area located within national borders and is part of a whole (Prosser, 2000, p. 4). In the case of the present study, the regions are composed of several counties and are part of Romania. However, it is important to mention that the region from a tourist point of view does not necessarily have to be within the limits of political-administrative borders (Dredge and Jenkins, 2003, p. 394). Coform Association of Accredited Public Policy Advocates to the European Union (2015), in Europe there are 15 tourist regions: Adriatic Coast, Baltic States, Atlantic Coast, Balkan Peninsula, Benelux, Black Sea, Carpathian Mountains, Central Europe, Iberian Peninsula, Islands and archipelagos, Mediterranean Sea, North Sea, Rhine Valley, Scandinavia and Alps. Romania is part of the Balkan Peninsula region and the Carpathian Mountains region. In Romania there are also historical regions: Banat, Bucovina, Crișana, Dobrogea, Maramureș, Moldova, Muntenia, Oltenia and Transylvania (Stăncioiu, et al., 2011, p. 140). In addition to these areas, in Romania, there are also development regions that are called cardinal points or cardinal points and historical regions and that are made up of several counties. Thus, the development regions of Romania are: North-East, South-East, SouthMuntenia, South-West Oltenia, West, North-West, Center, Bucharest-Ilfov (Ministry of Regional Development and Public Administration, 2013, p. 4).

Regional tourism means the tourist activity that takes place in a certain region. Regional tourism can be classified according to geographical area, more precisely tourism in mountain areas, tourism in maritime areas, tourism in rural areas, tourism in urban areas (Batista e Silva, et al., 2020, p. 2). Regional tourism includes tourism in rural and urban areas, in coastal areas and is characterized by the essence of the areas in which it takes place (Prosser, 2000, p. 4). In other words, regional tourism is not a particular form of tourism, but involves tourism activities in a well-defined area. In other words, given the fact that the development regions in Romania are made up of counties, it can be admitted that these are welldefined areas.

Pascariu and Țigănașu (2014, p. 1103) calculated the Tourism Index of the Development Regions in Romania, setting four categories of destinations: mature tourist destinations, medium to high level tourist destinations, medium to low level tourist destinations and tourist destinations in the initial stage. Thus, the Bucharest-Ilfov Development Region is part of the category of medium to low level tourist destinations, and the North-West, North-East, Center, South-East, South-Muntenia, South-West Oltenia and West Development Regions fall among the tourist destinations in the initial stage (Pascariu and Țigănașu, 2014, p. 1104). The Tourist Index measures the tourist intensity. In other words, in the Development Regions of Romania, the tourist intensity is low.

In the period 1992-2014, the tourist pressure at the level of the development regions of Romania, expressed by the ratio between the number of tourists and the area of the region increased on average in the case of the North-West, Center and Bucharest-Ilfov development regions and decreased on average in South-Muntenia, West, South-East, North-East, South-West Oltenia Development Regions (Gogonea, et al., 2017, p. 11). In other words, tourism density has increased in some development regions and decreased in others. In the case of the tourist pressure expressed by the ratio between the number of overnight stays and the surface of the region, there were reduced fluctuations in the case of the South-West Oltenia, South-Muntenia, North-East, North-West, West, while in the case of the Central Development Region and the Bucharest-Ilfov Development Region, there were average increases, and in the case of the South-East Development Region there was an average decrease (Gogonea, et al., 2017, p. 12). Thus, the number of overnight stays relative to the area of the region registered a relatively 
constant rate, increasing or decreasing depending on each region. The tourist intensity and the pressure that tourism has on the developement regions of Romania differ from one region to another.

\subsection{The relationship Tourism - Gross Domestic Product (GDP)}

The economic implications of tourism are undeniable and numerous. Among them can be listed: tourism generates national income, tourism is a factor of capitalization of resources, tourism mitigates inflation, tourism contributes to the diversification of economic units, tourism is a creator of new jobs, tourism encourages increased investment, tourism stimulates external interaction (Dumitru, 2012, pp. 43-46). Also, tourism, manifested by tourist demand, involves the consumption of goods and services specific and non-specific to the tourism sector, which leads to increased production (Minciu, 2004, p. 26). Thus, tourism is an economic sector that can make an important contribution to national economies. At the same time, it goes without saying that in areas or countries where tourism is less developed and its contribution to the formation of Gross Domestic Product is more modest (Minciu, 2004, p. 26).

According to the World Travel \& Tourism Council (2021), the tourism sector contributed to the formation of the global Gross Domestic Product in 2019 by about $10.4 \%$, while in 2020, due to the Covid19 pandemic, the contribution of tourism to the formation of the global Gross Domestic Product was only 5.5\%. Also, in Romania, the tourism sector contributed to the formation of the Gross Domestic Product in 2019 by approximately $6.1 \%$, while in 2020 , due to the Covid 19 pandemic, the contribution of tourism to the formation of the Gross Domestic Product was only 2.9\% ( World Travel \& Tourism Council, 2021).

The influence of tourism on the Gross Domestic Product (GDP) can be studied by relating several tourism indicators to the value of GDP, such as the number of tourists, the number of tourism employees or the expenses incurred by tourists. There is a possibility that tourism will have a positive or negative influence on the Gross Domestic Product (GDP). For example, the number of tourists arriving in the Yogyakata region of Indonesia has a positive influence on GDP, as an increase in the number of tourists by $1 \%$ will generate an increase in Gross Domestic Product by $0.23 \%$ (Feriyanto, 2020, p. 751), while in Sri Lanka, there is a negative relationship between the number of tourists and the Gross Domestic Product (Nisthar and Vijayakumar, 2016, p. 57). At the Romanian level, it has been demonstrated that both in the short and long term, between the number of international tourists and the Gross Domestic Product there is a one-way causal relationship - GDP - number of tourists (Badulescu, et al., 2020, pp. 877-878 ). In other words, the increase of the Gross Domestic Product of Romania will generate the increase of the number of international tourists arriving on the territory of our country. Also, between the number of tourists arriving in the accommodation units from the eight development regions of Romania, the number of tourism employees and the Gross Domestic Product there is a long-term interdependence relationship, and the first two mentioned indicators directly influence the third indicator (Gogonea and Zaharia, 2019, pp. 5). In terms of revenue, at European level, between the revenues generated by tourism and the Gross Domestic Product there is a bidirectional causal relationship (Caglayan, Șak and Karymshakov, 2012, p. 598). In other words, tourist flows contribute to the formation of Gross Domestic Product, but also the level of Gross Domestic Product contributes to attracting tourist flows.

\section{Research methodology}

The present study is of a quantitative type, and a simple linear regression was used. Statistical tests such as the F test, the ADF test (Augumented Dickey-Fuller), the White test, the Breusch-Godfrey test, the Jarque-Bera test and the Huber-White correction method were used in the analysis. The series used in the study are time series, given the time interval between 1995 and 2020.

The purpose of this study is to find out the influence of the number of tourists arriving in the development regions of Romania on the Gross Domestic Product. A dependent variable and an independent variable were taken into account to perform the analysis. The dependent variable is represented by the Gross Domestic Product, and the independent variable is represented by the number of tourists arriving in the development regions of Romania. The statistical program EViews was used for data analysis.

The steps that were followed in analyzing the data series were:

1. Collecting data from the website of the National Institute of Statistics; 
2. Checking the validity of the regression model between the data series;

3. Checking the stationarity of data series and stationary non-stationary series;

4. Applying regression to stationary data series;

5. Testing the heteroskedasticity hypothesis;

6. Testing the hypothesis of autocorrelation of errors;

7. Testing the hypothesis of normal error distribution;

8. Correction of the regression model, where appropriate;

9. Interpretation of results.

For heteroskedasticity, there are two hypotheses, namely, the null hypothesis marked with H0 - the errors are homoskedastic and the alternative hypothesis, marked with $\mathrm{H} 1$ - the errors are heteroskedastic. For the lack of autocorrelation of errors there is the null hypothesis, denoted by $\mathrm{H} 0$ - the errors are not autocorrelated and the alternative hypothesis, denoted by H1 - the errors are autocorrelated. For the normality of the error distribution there are also two hypotheses, more precisely the null hypothesis, denoted by $\mathrm{H} 0$ - the errors are normally distributed and the alternative hypothesis, denoted by $\mathrm{H} 1$ - the errors are not normally distributed. The White test was also used to test the heteroskedasticity, the Breusch-Godfrey test was used to test the error autocorrelation, and the Jarque-Bera test was used to test the normal error distribution. In order to accept null hypotheses, the probability of statistical tests must be higher than the significance threshold. In the case of this study, the significance threshold is 5\%.

The analyzed data series are presented in the table below. The data series are expressed in thousands of RON, respectively thousands of tourists.

Table no. 1: The data series used

\begin{tabular}{|c|c|c|c|c|c|c|c|c|c|}
\hline Year & $\begin{array}{c}\text { GDP / in- } \\
\text { habitant } \\
\text { (RON) }\end{array}$ & $\begin{array}{c}\text { Bucha- } \\
\text { rest-Ilfov }\end{array}$ & Center & $\begin{array}{c}\text { North- } \\
\text { East }\end{array}$ & $\begin{array}{c}\text { North- } \\
\text { west }\end{array}$ & $\begin{array}{c}\text { South } \\
\text { East }\end{array}$ & $\begin{array}{c}\text { South- } \\
\text { Muntenia }\end{array}$ & $\begin{array}{c}\text { South- } \\
\text { West } \\
\text { Oltenia }\end{array}$ & West \\
\hline 1995 & 0.33 & 867 & 1173 & 819 & 805 & 1395 & 816 & 544 & 648 \\
\hline 1996 & 0.50 & 649 & 1234 & 780 & 781 & 1293 & 729 & 506 & 619 \\
\hline 1997 & 1,13 & 718 & 980 & 662 & 619 & 1129 & 667 & 433 & 515 \\
\hline 1998 & 1,64 & 675 & 927 & 635 & 605 & 1171 & 641 & 374 & 520 \\
\hline 1999 & 2,45 & 624 & 855 & 568 & 601 & 1007 & 569 & 343 & 539 \\
\hline 2000 & 3,60 & 520 & 868 & 5430 & 559 & 980 & 552 & 327 & 568 \\
\hline 2001 & 5,23 & 487 & 836 & 534 & 596 & 994 & 545 & 337 & 541 \\
\hline 2002 & 7,02 & 553 & 752 & 535 & 629 & 984 & 548 & 348 & 493 \\
\hline 2003 & 8,89 & 589 & 842 & 553 & 636 & 1018 & 571 & 324 & 520 \\
\hline 2004 & 11,40 & 729 & 986 & 618 & 698 & 1133 & 575 & 361 & 535 \\
\hline 2005 & 13,45 & 831 & 1067 & 621 & 733 & 1107 & 573 & 3340 & 535 \\
\hline 2006 & 16,17 & 900 & 1164 & 678 & 780 & 1080 & 627 & 370 & 613 \\
\hline 2007 & 20,38 & 996 & 1329 & 717 & 889 & 1231 & 729 & 403 & 674 \\
\hline 2008 & 26,28 & 1038 & 1291 & 725 & 908 & 1308 & 750 & 429 & 673 \\
\hline 2009 & 26,06 & 989 & 1072 & 656 & 732 & 1157 & 591 & 366 & 575 \\
\hline 2010 & 26,10 & 1125 & 1126 & 620 & 702 & 1044 & 572 & 337 & 542 \\
\hline 2011 & 27,73 & 1282 & 1435 & 696 & 799 & 1134 & 615 & 426 & 639 \\
\hline 2012 & 29,50 & 1352 & 1654 & 740 & 852 & 1263 & 692 & 454 & 674 \\
\hline 2013 & 31,76 & 1437 & 1859 & 756 & 899 & 1166 & 679 & 460 & 684 \\
\hline 2014 & 33,62 & 1630 & 1953 & 812 & 972 & 1178 & 706 & 484 & 727 \\
\hline 2015 & 35,91 & 1850 & 2332 & 939 & 1140 & 1347 & 852 & 582 & 875 \\
\hline 2016 & 38,75 & 2065 & 2585 & 1084 & 1316 & 1506 & 914 & 630 & 899 \\
\hline 2017 & 43,78 & 2202 & 2856 & 1187 & 1581 & 1642 & 974 & 736 & 960 \\
\hline 2018 & 48,86 & 2279 & 3053 & 1257 & 1721 & 1802 & 1036 & 739 & 1015 \\
\hline 2019 & 54,61 & 2236 & 3173 & 1352 & 1766 & 1898 & 1084 & 791 & 1071 \\
\hline 2020 & 54,61 & 616 & 153 & 691 & 791 & 1271 & 543 & 470 & 479 \\
\hline
\end{tabular}

Source: Data taken by authors from the website of the National Institute of Statistics, http://statistici.insse.ro:8077/tempo-online/ (accessed June 10, 2021). 


\section{Results}

The verification of the validity of the model between the data series was performed using the $\mathrm{F}$ test, at a significance threshold of $5 \%$. Thus, valid regression models were those for which the probability of the $\mathrm{F}$ test was less than 5\%. Valid regression models were between the following data series:

- GDP and the number of tourists arriving in the Bucharest-Ilfov Development Region (Probability of the F test $=0.000873$ );

- GDP and number of tourists arriving in the North-West Development Region (Probability of the $\mathrm{F}$ test $=0.000027$ );

- GDP and number of tourists arriving in the South-East Development Region (Probability of F test $=0.001131$ );

- GDP and number of tourists arriving in the South-Muntenia Development Region (Probability of the F test $=0.007442$ );

- GDP and number of tourists arriving in the Western Development Region (Probability of the $\mathrm{F}$ test $=0.035277)$.

Following the application of the Augmented Dickey-Fuller (ADF) test, which verified the stationarity of the data series, the following results were obtained:

- The GDP (Gross Domestic Product) series is a stationary series at the first difference;

- The number of tourists arriving in the Bucharest-Ilfov Development Region and the number of tourists arriving in the North-West Development Region are stationary series as such;

- The number of tourists arriving in the South-East Development Region, the number of tourists arriving in the South-Muntenia Development Region and the number of tourists arriving in the West Development Region are stationary series at the first difference.

After the series stationary and applying simple regression, the hypotheses of heteroskedasticity, autocorrelation of errors and normal distribution of errors were tested, and the results are presented in the following table:

Table no. 2: The hypotheses of heteroskedasticity, autocorrelation and normal error distribution

\begin{tabular}{|c|c|c|c|c|c|c|}
\hline Data series & Hetero-skedasticity & Argu-ment & $\begin{array}{c}\text { Autocorrelation of } \\
\text { errors }\end{array}$ & $\begin{array}{c}\text { Argu- } \\
\text { ment }\end{array}$ & \begin{tabular}{|c|} 
Normal \\
error \\
distribu-tion
\end{tabular} & $\begin{array}{c}\text { Argu- } \\
\text { ment }\end{array}$ \\
\hline $\begin{array}{l}\text { GDP and tourists } \\
\text { arriving in } \\
\text { Bucharest-Ilfov }\end{array}$ & HO - accepted & $\begin{array}{c}\text { Prob. F- } \\
\text { statistic } \\
(0.22)>0.05\end{array}$ & H0 - accepted & $\begin{array}{c}\text { Prob. F- } \\
\text { statistic } \\
(0.14)> \\
0.05\end{array}$ & HO - accepted & $\begin{array}{c}\text { Prob. } \\
\text { Jarque } \\
\text { Bera } \\
(0.21)> \\
0.05\end{array}$ \\
\hline $\begin{array}{l}\text { GDP and tourists } \\
\text { arriving in the } \\
\text { North-West }\end{array}$ & HO - accepted & $\begin{array}{c}\text { Prob. F- } \\
\text { statistic } \\
(0.59)>0.05\end{array}$ & H0 - accepted & $\begin{array}{c}\text { Prob. F- } \\
\text { statistic } \\
(0.34)> \\
0.05\end{array}$ & H0 - rejected & $\begin{array}{c}\text { Prob. } \\
\text { Jarque } \\
\text { Bera } \\
(0.02) \\
<0.05\end{array}$ \\
\hline $\begin{array}{l}\text { GDP and tourists } \\
\text { arriving in the } \\
\text { South-East }\end{array}$ & HO - accepted & $\begin{array}{c}\text { Prob. F- } \\
\text { statistic } \\
(0.56)>0.05\end{array}$ & H0 - rejected & $\begin{array}{c}\text { Prob. F- } \\
\text { statistic } \\
(0.04) \\
<0.05\end{array}$ & HO - accepted & $\begin{array}{c}\text { Prob. } \\
\text { Jarque } \\
\text { Bera } \\
(0.20)> \\
0.05\end{array}$ \\
\hline $\begin{array}{l}\text { GDP and tourists } \\
\text { arriving in } \\
\text { South-Muntenia }\end{array}$ & H0 - accepted & $\begin{array}{c}\text { Prob. F- } \\
\text { statistic } \\
(0.86)>0.05\end{array}$ & H0 - rejected & $\begin{array}{c}\text { Prob. F- } \\
\text { statistic } \\
(0.003) \\
<0.05\end{array}$ & H0 - accepted & $\begin{array}{c}\text { Prob. } \\
\text { Jarque } \\
\text { Bera } \\
(0.13)> \\
0.05 \\
\end{array}$ \\
\hline $\begin{array}{l}\text { GDP and tourists } \\
\text { arriving in the } \\
\text { West }\end{array}$ & H0 - accepted & $\begin{array}{c}\text { Prob. F- } \\
\text { statistic } \\
(0.69)>0.05\end{array}$ & $\mathrm{H} 0$ - rejected & $\begin{array}{c}\text { Prob. F- } \\
\text { statistic } \\
(0.008) \\
<0.05\end{array}$ & HO - accepted & $\begin{array}{c}\text { Prob. } \\
\text { Jarque } \\
\text { Bera } \\
(0.19)> \\
0.05\end{array}$ \\
\hline
\end{tabular}

Source: Made by the authors based on the data processed in EViews 
To correct the model, in the case of data series in which one or more null hypotheses were rejected, the Huber-White procedure was used. Thus, the models remained valid in all cases, as the probability of Wald F-statistic was less than the significance threshold of 5\%, and R-squared was lower than DurbinWatson, as follows:

- GDP and number of tourists arriving in the North-West Development Region - Wald F-statistic (0.000000) <0.05; R-squared (0.54) <Durbin-Watson test (1.27);

- GDP and number of tourists arriving in the South-East Development Region - Wald F-statistic $(0.005)<0.05 ;$ R-squared (0.37) < Durbin-Watson test (0.97);

- GDP and the number of tourists arriving in the South-Muntenia Development Region - Wald Fstatistic $(0.012)<0.05$; R-squared (0.27) <Durbin-Watson test $(0.79)$;

- GDP and the number of tourists arriving in the West Development Region - Wald F-statistic (0.006) $<0.05$; R-squared (0.17) < Durbin-Watson test (0.84).

Based on the validity of the models, the data series coefficients were interpreted, which show the influence of the independent variable on the dependent variable.

Table no. 3: The influence of the number of tourists arriving in the Bucharest-Ilfov Development Region on the Gross Domestic Product (GDP)

\begin{tabular}{|c|c|c|c|c|}
\hline Variable & Coefficient & Std. Error & t-Statistics & Prob. \\
\hline $\begin{array}{c}\text { Number of } \\
\text { tourists arriving } \\
\text { in the } \\
\begin{array}{c}\text { Bucharest-Ilfov } \\
\text { Development } \\
\text { Region }\end{array}\end{array}$ & 0.001882 & 0.000365 & 5.152773 & 0.0000 \\
\hline C & 33.59559 & 495,8686 & & \\
\hline R squared & 0.388499 & \multicolumn{3}{|c|}{ Mean dependent var 2170.976 } \\
\hline
\end{tabular}

Source: Made by the authors based on the data processed in EViews

When the number of tourists arriving in the Bucharest-Ilfov Development Region increases with one tourist, the GDP will increase by 0.001 Ron / inhabitant. Also, 38\% of the variation of the dependent variable is explained by the variation of the independent variable.

Table no. 4: The influence of the number of tourists arriving in the North-West Development Region on the Gross Domestic Product (GDP)

\begin{tabular}{|c|c|c|c|c|}
\hline Variable & Coefficient & Std. Error & t-Statistics & Prob. \\
\hline $\begin{array}{c}\text { Number of tourists } \\
\text { arriving in the North- } \\
\text { West Development } \\
\text { Region }\end{array}$ & 0.003772 & 0.000310 & 12.16722 & 0.0000 \\
\hline C & -1196.139 & 420.0902 & -2.847338 & 0.0091 \\
\hline R squared & 0.542629 & \multicolumn{3}{|c|}{ Mean dependent var 2170.976 } \\
\hline
\end{tabular}

Source: Made by the authors based on the data processed in EViews

When the number of tourists arriving in the North-West Development Region increases with one tourist, the GDP will increase by 0.003 Ron / inhabitant. Also, $54 \%$ of the variation of the dependent variable is influenced by the variation of the independent variable.

Table no. 5: The influence of the number of tourists arriving in the South-East Development Region on the Gross Domestic Product (GDP)

\begin{tabular}{|c|c|c|c|c|}
\hline Variable & Coefficient & Std. Error & t-Statistics & Prob. \\
\hline $\begin{array}{c}\text { Number of tourists } \\
\text { arriving in the South- } \\
\begin{array}{c}\text { East Development } \\
\text { Region }\end{array}\end{array}$ & 0.006493 & 0.002101 & 3.090322 & 0.0052 \\
\hline C & 2203.231 & 289.3422 & & \\
\hline R squared & 0.375343 & \multicolumn{3}{|c|}{ Mean dependent var 2170.976 } \\
\hline
\end{tabular}

Source: Made by the authors based on the data processed in EViews 
As the number of tourists arriving in the South-East Development Region increases by one tourist, the GDP will increase by 0.006 Ron / inhabitant. Also, 37\% of the variation of the dependent variable is influenced by the variation of the independent variable.

Table no. 6: The influence of the number of tourists arriving in the South-Muntenia Development Region on the Gross Domestic Product (GDP)

\begin{tabular}{|c|c|c|c|c|}
\hline Variable & Coefficient & Std. Error & t-Statistics & Prob. \\
\hline $\begin{array}{c}\text { Number of tourists arriving in the South- } \\
\text { Muntenia Development Region }\end{array}$ & 0.007304 & 0.002705 & 2,700432 & 0.0128 \\
\hline C & 2250.817 & 313.1671 & 7.187270 & 0.0000 \\
\hline R squared & 0.272464 & \multicolumn{2}{|c|}{ Mean dependent var 2170.976 } \\
\hline
\end{tabular}

Source: Made by the authors based on the data processed in EViews

When the number of tourists arriving in the South-Muntenia Development Region increases with one tourist, the GDP will increase by 0.007 Ron / inhabitant. Also, $27 \%$ of the variation of the dependent variable is influenced by the variation of the independent variable.

Table no. 7: The influence of the number of tourists arriving in the Western Development Region on the Gross Domestic Product (GDP)

\begin{tabular}{|c|c|c|c|c|}
\hline Variable & Coefficient & Std. Error & t-Statistics & Prob. \\
\hline $\begin{array}{c}\text { Number of tourists arriving in the } \\
\text { Western Development Region }\end{array}$ & 0.005624 & 0.001889 & 2.977791 & 0.0067 \\
\hline C & 2208,939 & 332.5567 & 6.642294 & 0.0000 \\
\hline R squared & 0.178682 & \multicolumn{2}{|c|}{ Mean dependent var 2170.976 } \\
\hline
\end{tabular}

Source: Made by the authors based on the data processed in EViews

When the number of tourists arriving in the Western Development Region increases with one tourist, the GDP will increase by 0.005 Ron / inhabitant. Also, $17 \%$ of the variation of the dependent variable is influenced by the variation of the dependent variable.

The hierarchy of development regions in terms of the increase of the Gross Domestic Product, generated by the increase of the number of tourists with one tourist is the following: South-Muntenia Development Region (0.007 RON/inhabitant), South-East Development Region (0.006 RON/inhabitant), West Development Region (0.005 Ron/inhabitant), North-West Development Region (0.003 Ron/inhabitant) and Bucharest-Ilfov Development Region (0.001 Ron/inhabitant).

\section{Conclusions}

Tourism is an indisputable source of the formation of the Gross Domestic Product, but the contribution that tourism has to the formation of this economic aggregate differs from one region to another. Although in previous studies, the Bucharest-Ilfov Development Region is among the medium to low level destinations in terms of tourist intensity, and the other regions are in an initial stage (Pascariu and Țigănașu, 2014), this region is ranked last in terms of the contribution of tourism, expressed by the number of tourists arriving in the region, to the growth of Gross Domestic Product. This indicates that in this region, the tourism sector is ahead of other economic sectors in the formation of the Gross Domestic Product and that the other development regions place a greater emphasis on the tourism sector. Also, the results of a previous study are true, according to which there is an interdependence between the number of tourists arriving in the development regions of Romania and the Gross Domestic Product (Gogonea and Zaharia, 2019), as between the number of tourists arriving in the development regions of Romania and the Gross Domestic Product positive correlations were found. Thus, the greatest influence of the number of tourists on the Gross Domestic Product was found in the North-West Development Region (54\%), although when the number of tourists increases with one tourist, the Gross Domestic Product increases only by 0.003 Ron / inhabitant. In other words, this indicates that a large number of tourists does not necessarily mean generating a considerable increase in Gross Domestic Product. These results can impel the tourist service providers and the local authorities in finding solutions that allow the efficiency of the tourist activity, in the sense that a small number of tourists make a maximum of expenditures in the development regions of Romania. The limitation of the present research is that only one independent variable was used. 


\section{References}

Association of Accredited Public Policy Advocates to the European Union, 2015. 15 Tourism Regions in Europe. [online] Available at <http://www.aalep.eu/15-tourism-regions-europe> [Accessed 21 June 2021].

Badulescu, A., Badulescu, D., Simut, R. and Dzitac., S. 2020. Tourism - Economic growth nexus. The case of Romania. Technological and Economic Development of Economy, 26 (4), pp. 867-884.

Batista e Silva, F., Barranco, R., Proietti, P., Pigaiani, C. and Lavalle, C., 2020. A new European regional tourism typology based on hotel location patterns and geographical criteria. Annals of Tourism Research, [e-journal], pp.1-6. https://doi.org/10.1016/j.annals.2020.103077.

Caglayan, E., Şak, N. and Karymshakov, K., 2012. Relationship between tourism and economic growth: a panel Granger causality approach. Asian Economic and Financial Review, 2 (5), pp. 591-602.

Dredge, D. and Jenkins, J,. 2003. Destination place identity and regional tourism policy. Tourism Geographies, 5 (4), pp. 383-407.

Dumitru, N., 2012. The contribution of tourism in the process of economic growth. Journal of Tourism, pp. 41-47.

Feriyanto, N., 2020. Economic and Tourism Factors Affecting the Real Gross Regional Domestic Product: A Case Study. European Research Studies, 23 (3), pp. 736-756.

Gogonea, R.M. and Zaharia, M., 2019. The employed population and tourism flows in Romania's regional economic recovery. A cointegration analysis. Journal of tourism - studies and research in tourism, (27), pp. 1-6.

Gogonea, R.M., Baltălungă, A.A., Nedelcu, A. and Dumitrescu, D., 2017. Tourism Pressure at the Regional Level in the Context of Sustainable Development in Romania. Sustainability, [e-journal] 9, pp. 1-24. doi: 10.3390 / su9050698.

National Institute of Statistics, 2021. Statistical databases - Tempo - Online time series. [online] Available at <http://statistici.insse.ro:8077/tempo-online/> [Accessed June 10, 2021].

Karagozzeren, S., 2018. Determination of number of arriving tourists and night spent in accommodation relations with economic growth: the case of Turkey. Prizren Social Science Journal, 2 (2), pp. 210-224.

Lazăr, D. and Pop, F., 2012. A note on tourism demand in Romania: Time series analysis and relationship with economic growth. Managerial Challenges of the Contemporary Society. Proceedings, 4, pp. 7-11, Cluj-Napoca: Babes Bolyai University.

Minciu, R., 2004. Tourism Economics. Bucharest: Uranus Publishing House.

Ministry of Regional Development and Public Administration, 2013. National Strategy for Regional Development. [online] Available at <https://inforegio.ro/images/Documente_de_programare/Strategia_Nationala _Dezvoltare_Regiunea_-_iulie_2013.pdf> [Accessed June 19, 2021].

Nisthar, S. and Vijayakumar, S., 2016. An Analysis of the Relationship between the Real Gross Domestic Production (RGDP) and Tourism Sector: An Econometric Study on Sri Lankan Perspective. International Journal on Global Business Management \& Research, 5 (1), pp. 47-63.

Pascariu, G.C. and Țigănașu, R., 2014. Tourism and sustainable regional development in Romania and France: an approach from the perspective of New Economic Geography. Economic Amphitheater, 16 (8), pp. 1089-1109.

Popescu, D., Oehler-Şincai, I.M., Bulin, D. and Tănase, I.A., 2018. ECE-16: A cluster analysis based on tourism competitiveness and correlations with major determinants. Economic Amphitheater, 20 (12), pp. 597-616.

Pripoaie, R., 2017. Analysis of Disparities between Regional GDP Per Capita by Region. EuroEconomica, 36 (2), pp. 211-215.

Prosser, G., 2000. Regional Tourism Research: A Scoping Study. Center for Regional Tourism Research, pp. $1-29$.

Stăncioiu, A.F., Teodorescu, N., Pârgaru, I., Vlădoi, A.D. and Băltescu, C., 2011. The Image of the Tourism Destination - a Supporting Element in the Development of the Regional Tourism Brand Study Case: Muntenia. Theoretical and Applied Economics, 18 (2), pp. 139-152.

World Travel \& Tourism Council, 2021. WTTC Economic Impact Research. [online] Available at $<$ https://wttc.org/Research/Economic-Impact> [Accessed June 24, 2021]. 